\title{
PENERAPAN MODEL KOOPERATIF TIPE JIGSAW UNTUK MENINGKATKAN HASIL BELAJAR IPA-BIOLOGI PADA KONSEP PENCEMARAN LINGKUNGAN KELAS VII
}

\author{
Desty Carroline $^{1^{*}}$, Irdam Idrus ${ }^{1}$, Yennita $^{1}$ \\ ${ }^{1}$ Program Studi Pendidikann Biologi, Fakultas Keguruan dan Ilmu Pendidikan, Universitas Bengkulu \\ email: destycarroline12@gmail.com
}

\begin{abstract}
Abstrak
Penelitian ini bertujuan untuk : 1) mendeskripsikan aktivitas mengajar guru dan aktivitas belajar peserta didik, 2) meningkatkan hasil belajar dengan menggunakan model pembelajaran kooperatif tipe Jigsaw dikelas VII.1 SMPN 8 Kota Bengkulu. Jenis penelitian ini adalah PTK dengan metode deskriptif. Penelitian ini terdiri dari 2 siklus, yaitu perencanaan, pelaksanaan, pengamatan dan refleksi. Subjek penelitian guru dan seluruh peserta didik kelas VII.1 SMPN 8 Kota Bengkulu. Instrumen penelitian yang digunakan adalah lembar observasi dan lembar tes. Hasil analisis data observasi aktivitas guru siklus I diperoleh rata-rata skor 27 (Baik), sedangkan pada siklus II meningkat menjadi 29 (Baik). Untuk hasil analisis data observasi aktivitas peserta didik juga mengalami peningkatan dari siklus I diperoleh rata-rata skor 27 (Baik) meningkat menjadi 29 (Baik). Sedangkan untuk presentase ketuntasan belajar klasikal yang diperoleh meningkat dari $65,38 \%$ (Belum tuntas) dengan rata-rata 63,15 pada siklus II menjadi 76,92\% (Tuntas) dengan rata-rata nilai 75,69.
\end{abstract}

Kata Kunci: Model Kooperatif Tipe Jigsaw, Aktivitas, Hasil Belajar

\begin{abstract}
This study aims to describe activity of teacher and students, as well as to describe learning outcomes of students with implementation of cooperative learning model (jigsaw type). This research is a Classroom Action Research with descriptive method. This research was conducted for two cycles, each cycle consist of planning, implementation, observation and reflection. The subject of this research was the reseacher and all the students of class VII.1 SMPN 8 Bengkulu city. The research instrument were observation and test. The score result for teacher activity in first cycle was 27 (good), increased to 29 (Good) in second cycle. The score result for student activity in first cycle was 27 (Good), increased to 29 (Good) in second cycle. Classical learning completeness of students in fisrt cycle was $65,38 \%$ with average score 63,15 , increased to $76,92 \%$ with average score 75,69 in second cycle.
\end{abstract}

Keyword: Cooperative Model Type Jigsaw, Activity, Learning outcomes

\section{PENDAHULUAN}

Proses pembelajaran di dalam kelas merupakan suatu dunia komunikasi tersendiri dimana terjadi pertukaran pikiran antara guru dan peserta didik untuk mengembangkan suatu ide. Di era reformasi ilmu pengetahuan dan teknologi seperti saat ini, perbaikan kegiaatan belajar dan mengajar harus diupayakan secara maksimal agar mutu pendidikan dapat meningkat. Peran guru dalam proses kegiatan belajar dan mengajar dapat mempengaruhi hasil belajar peserta didik.

Suparman (2014) menyatakan bahwa peran guru sebagai motivator adalah memberikan motivasi kepada peserta didik agar mereka melakukan kegiatan belajar mengajar dengan kehendak sendiri sesuai dengan tujuan belajar yang telah ditetapkan oleh kurikulum.

Sebagai seorang pendidik guru dituntut untuk memiliki kemampuan memilih dan menggunakan model pembelajaran dalam mengajar yang tepat serta sesuai dengan pokok bahasan tertentu dan tingkat perkembangan intelektual peserta didiknya. Salah satu model yang dapat diterapkan yaitu pembelajaran kooperatif.

Pembelajaran kooperatif adalah model pembelajaran yang mengutamakan kerjasama untuk mencapai tujuan pembelajaran. Pembelajaran kooperatif (Cooperative Learning) merupakan bentuk pembelajaran 
dengan peserta didik belajar dan bekerjasama dalam kelompok-kelompok kecil secara kolaboratif yang anggotanya terdiri dari 4-7 orang dengan struktur kelompok heterogen. Nur (2011) menyatakan bahwa dalam menyelesaikan tugas kelompok, setiap anggota kelompok harus saling bekerjasama dan saling membantu untuk memahami materi pelajaran. Salah satu model pembelajaran kooperatif yaitu tipe jigsaw.

Berdasarkan hasil observasi terhadap pembelajaran yang dilakukan guru IPA di SMP 8 Kota Bengkulu, diperoleh informasi bahwa guru telah mengetahui mengenai model pembelajaran Kooperatif tipe jigsaw, namun belum pernah menerapkannya, khususnya pada mata pelajaran IPA-Biologi. Biasanya guru hanya menggunakan model pembelajaran ceramah dan tanya jawab. Hal ini mempengaruhi hasil belajar peserta didik. Terlihat dari hasil ulangan harian peserta didik yang masih banyak dibawah KKM $\geq 75$, yaitu hanya 10 orang yang tuntas dari 26 peserta didik. Setelah melakukan observasi peneliti termotivasi untuk melakukan penelitian langsung ke sekolah tersebut dengan menerapkan model pembelajaran tipe jigsaw.

Dari masalah pembelajaran yang ada di

SMP 8 Kota Bengkulu tersebut, peneliti menerapkan model pembelajaran kooperatif tipe jigsaw yang diharapkan dapat meningkatkan aktivitas mengajar guru dan aktifitas belajar peserta didik serta dapat meningkatkan hasil belajar peserta didik.

\section{METODE PENELITIAN}

Penelitian ini merupakan penelitian tindakan kelas (PTK) dengan metode deskriptif dan dilakukan dalam 2 siklus. Setiap siklus terdiri dari empat tahapan yakni; Perencanaan (Planning), (2) Pelaksanaan Tindakan (Acting), (3) Observasi (Observing) dan (4) Refleksi (Reflecting), dengan materi yang diajarkan yaitu materi Pencemaran Lingkungan. Penelitian ini dilakukan pada peserta didik kelas VII.1 SMPN 8 Kota Bengkulu berjumlah 26 orang. Teknik pengumpulan data berupa observasi dan tes. Intrumen yang digunakan berupa lembar observasi dan lembar tes dalam bentuk essay. Teknik analisis data observasi dilakukan secara kualitatif dan dihitung menggunakan rumus rerata skor :

Rerata skor $=\frac{\text { jumlah } \text { skor }}{\text { jumlah observer }}($ Sudjana, 1989).

Kategori aktivitas mengajar guru dan aktivitas belajar peserta didik ditentukan dengan rentang nilai seperti pada Tabel 1.

Tabel 1. Kategori Penilaian Aktivitas Mengajar Guru Dan Aktivitas Belajar Peserta Didik

\begin{tabular}{cc}
\hline Rentang Nilai & Kategori Penilaian \\
\hline $10-16$ & Kurang \\
$17-23$ & Cukup \\
$24-30$ & Baik \\
\hline
\end{tabular}

Untuk menghitung rerata hasil belajar peserta didik menggunakan rumus :

$\bar{X}=\frac{\sum x}{N}$ (Sudjana, 1989)

Keterangan :

$\bar{X}=$ nilai rata-rata kelas

$\sum x=$ jumlah nilai peserta didik

$\mathrm{N}=$ banyak peserta didik

Untuk menghitung persentase ketuntasan belajar klasikal peserta didik dapat menggunakan rumus :

$K B=\frac{N s \times 100 \%}{N}$ (Sudjana, 1989).

Keterangan :

$\mathrm{KB}=$ presentase ketuntasan belajar

$\mathrm{Ns}=$ jumlah peserta didik yang mendapat nilai $\geq 75$ (KKM SMP N 08 Kota Bengkulu)

$\mathrm{N}=$ jumlah peserta didik

\section{HASIL DAN PEMBAHASAN}

Berdasarkan penelitian yang telah dilakukan, aktivitas mengajar guru dan belajar peserta didik dalam kegiatan pembelajaran dengan model kooperatif tipe jigsaw dapat dilihat pada Tabel 2.

Tabel 2. Data Hasil Observasi Aktivitas Mengajar Guru Dan Aktivitas Belajar Peserta Didik

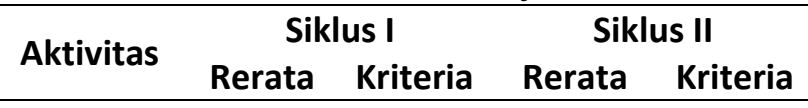




\begin{tabular}{ccccc}
\hline $\begin{array}{c}\text { Aktivitas } \\
\text { guru }\end{array}$ & 27 & Baik & 29 & Baik \\
$\begin{array}{c}\text { Aktivitas } \\
\text { peserta } \\
\text { didik }\end{array}$ & 27 & Baik & 29 & Baik \\
\hline
\end{tabular}

Aktivitas mengajar guru dan aktivitas belajar peserta didik pada siklus I dan siklus II sudah tergolong ke dalam kriteria baik. Pada tahap memberikan apersepsi, motivasi tujuan pembelajaran dan mengajukan gambar berupa fenomena alam peserta didik terlihat terlibat aktif dalam menjawab pertanyaan yang diajukan oleh guru. Hal ini sesuai dengan pendapat Sudjana (2009) bahwa pemberian apersepsi sebelum dimulainya pembelajaran kegiatan pembelajaran dapat membangkitkan rasa ingin tahu peserta didik mengenai materi yang akan dipelajari. Guru juga memotivasi peserta didik untuk mendengarkan dan memperhatikan ketika menyampaikan tujuan pembelajaran. Selain menjelaskan guru juga menuliskan tujuan pembelajaran di papan tulis, kemudian guru juga menjelaskan tentang proses pembelajaran dengan menggunakan metode pembelajaran tipe jigsaw.

Pada tahap mengorganisasikan peserta didik dalam kelompok belajar, guru membentuk peserta didik menjadi 4 kelompok asal, setelah terbentuk kelompok asal peserta didik dibagi lagi menjadi 4 kelompok sebagai kelompok ahli berdasarkan pembagian sub topik yang berbeda. Pembagian kelompok asal dibagi secara heterogen. Hal ini sesuai dengan pendapat Slavin (2014) yang menyatakan bahwa pembelajaran kooperatif adalah salah satu model pembelajaran dimana peserta didik belajar dan bekerja dalam kelompok-kelompok secara kolaboratif dengan struktur kelompok heterogen. Setelah kelompok asal terbentuk, guru membagikan gulungan kertas yang berisikan nomor kepada setiap kelompok asal. Setiap peserta didik yang telah mendapatkan nomor membentuk kelompok lagi yakni sebagai kelompok ahli. Sebelum peserta didik membentuk kelompok ahli guru membagikan Lembar Diskusi Peserta Didik ke setiap kelompok asal, masing-masing kelompok asal akan mendapatkan 4 Lembar Diskusi Peserta
Didik dengan materi diskusi yang berbedabeda. Selanjutnya guru mengintruksikan peserta didik untuk membentuk kelompok ahli berdasarkan nomor yang telah mereka dapatkan menjadi 4 kelompok, yakni nomor 1 dan 2 menjadi kelompok ahli mengenai Materi Pencemaran Air yang disebabkan oleh Limbah Industri, nomor 3 dan 4 menjadi kelompok ahli mengenai Pencemaran Air yang disebabkan oleh Limbah Detergen, nomor 5 menjadi kelompok ahli mengenai Pencemaran Air yang disebabkan oleh Limbah Rumah Tangga dan nomor 6 dan 7 menjadi kelompok ahli mengenai Pencemaran Air yang disebabkan oleh Tumpahan Minyak Di Laut. Menurut Majid (2014) dengan diberikannya materi yang berbeda-beda, peserta didik akan belajar untuk bertanggung jawab terhadap tugas yang diberikan oleh guru.

Pada siklus II dilakukan kegiatan yang sama, yaitu guru membentuk peserta didik menjadi kelompok asal, lalu guru membagikan Lembar Diskusi Peserta Didik. Kemudian guru membagikan kelompok ahli yang sama dengan kelompok ahli pada siklus I sebelumnya dengan materi yang berbeda dari materi sebelumnya yakni peserta didik yang mendapatkan nomor 1 dan 2 menjadi kelompok ahli materi Pencemaran Udara yang disebabkan oleh Asap Pabrik, nomor 3 dan 4 menjadi kelompok ahli materi Pencemaran Udara yang disebabkan oleh Asap Kendaraan, nomor 5 menjadi kelompok ahli Pencemaran Tanah yang disebabkan Pestisida Petani, nomor 6 dan 7 menjadi kelompok ahli Pencemaran Tanah yang disebabkan oleh Tumpukan Sampah.

Pada saat pembagian kelompok ahli di siklus I dan siklus II, peserta didik menyimak penjelasan pembagian dari guru, kemudian mendiskusikan sub topik yang telah diberikan bersama anggota kelompok. Menurut Abdulhak (2001), pembelajaran kooperatif dilaksanakan melalui sharing proses antara peserta didik, sehingga dapat mewujudkan pemahaman bersama antara peserta didik itu sendiri.

Pada tahap membimbing dan memantau kelompok belajar dan berdiskusi, guru membimbing dan memantau berjalannya 
proses pembelajaran. Pada siklus I peneliti mengalami kendala, yaitu suasana kelas yang kurang kondusif, kebingungan peserta didik dengan model pembelajaran yang dilakukan sehingga menyebabkan waktu pelaksanaan tidak sesuai dengan yang telah direncanakan. Pada siklus II, proses pembelajaran bisa berjalan dengan baik dikarenakan peserta didik sudah dapat beradaptasi dengan proses pembelajaran dan sebagian besar peserta didik sudah mau untuk bekerjasama dalam kelompok untuk berdiskusi. Hal ini sesuai dengan pendapat Hanafiah (2010) yang menyatakan bahwa, dari segi psikologis anak-anak cenderung mengikuti pembelajaran secara berkelompok dimana peserta didik belajar untuk bersosialisasi bersama peserta didik lainnya. Setelah dilakukan diskusi, tahapan selanjutnya perwakilan peserta didik dari setiap masingmasing kelompok asal mempresentasikan hasil diskusi mereka di depan kelas.

Pada tahap ini ketika perwakilan dari setiap kelompok maju ke depan untuk mempresentasikan hasil diskusinya, peserta didik yang lainnya ikut menanggapi atau memberikan pertanyaan. Pada kegiatan ini terlihat peserta didik sangat aktif saat menyampaikan pendapatnya. Hal ini sesuai dengan pernyataan Isjoni (2010) yang menyatakan bahwa pembelajaran menggunakan metode kooperatif bisa melatih peserta didik untuk memiliki keterampilan berfikir maupun sosialisasi, seperti keterampilan untuk mengemukakan pendapat, menerima saran dan masukan dari orang lain. Selain itu guru juga ikut mempertegas jawaban peserta didik yang dianggap masih kurang tepat. Hal ini sesuai dengan pendapat Ardianto (2013) bahwa dengan cara mempertegas jawaban peserta didik seorang guru dapat meningkakan kepercayaan diri peserta didik dalam mengemukakan pendapatnya.

Pada tahap evaluasi guru membimbing peserta didik untuk menyimpulkan hasil pembelajaran serta mengamati pemahaman peserta didik menggunakan tes. Pada siklus I kedua pengamat memberi penilaian cukup karena guru hanya membimbing 2 perwakilan kelompok saja dalam memberikan kesimpulan dari pembelajaran yang telah dilakukan. Tetapi pada siklus II guru membimbing 4 kelompok untuk memberikan kesimpulan pada pembelajaran yang telah dilakukan. Rahmaeta (2012) menyatakan bahwa dengan memberikan kesimpulan diharapkan peserta didik paham dengan proses pembelajaran yang telah dilakukan.

Setelah menyimpulkan peserta didik diminta untuk mengerjakan tes. Tahap ini dilakukan setelah proses pembelajaran, bertujuan agar guru dapat mengevaluasi pemahaman peserta didik setelah mengikuti proses pembelajaran dengan menggunakan metode kooperatif tipe jigsaw. Hal ini sesuai dengan pendapat Siska (2014), bahwa evaluasi merupakan istilah untuk mengukur dan menilai berdasarkan data yang telah terkumpul kemudian dilakukan refleksi.

Hasil belajar peserta didik yang diperoleh dari tes tertulis ditampilkan pada Tabel 3:

Tabel 3. Hasil Belajar Peserta Didik Siklus I dan Siklus II

\begin{tabular}{lcc}
\hline & \multicolumn{2}{c}{ Siklus } \\
\cline { 2 - 3 } & I & II \\
\hline Rata-rata & 63.15 & 75.69 \\
\hline $\begin{array}{l}\text { Presentase } \\
\text { ketuntasan hasil } \\
\text { belajar peserta } \\
\text { didik (\%) }\end{array}$ & 65.38 & 76,92 \\
\hline Kriteria & & \\
& Tidak & Tuntas \\
& tuntas & \\
\hline
\end{tabular}

Berdasarkan Tabel 3 dapat diketahui bahwa terjadi peningkatan hasil belajar dari siklus I ke siklus II. Peningkatan terjadi karena sudah dilakukannya perbaikan dalam proses pembelajaran baik aktivitas mengajar guru dan aktivitas belajar peserta didik sehingga hasil belajar peserta didik yang diperoleh mendapatkan hasil yang diinginkan. Hal ini sesuai dengan pendapat Slavin (2014) bahwa dengan model pembelajaran kooperatif tipe jigsaw dapat meningkatkan hasil belajar peserta didik karena model pembelajaran ini menjadikan peserta didik lebih bertanggunng 
jawab secara individu sehingga peserta didik harus dapat bekerjasama dan paham saat mereka melakukan diskusi kelompok. Hasil penelitian ini sependapat dengan hasil penelitian Yuliana (2012), yang menyatakan bahwa penerapan model pembelajaran kooperatif tipe jigsaw dapat meningkatkan hasil belajar peserta didik.

Pada siklus I diketahui bahwa hasil belajar peserta didik kelas VII.1 SMPN 8 Kota Bengkulu pada materi Pencemaran Lingkungan dengan menerapkan model pemelajaran kooperatif tipe jigsaw belum mencapai ketuntasan belajar klasikal yang telah ditetapkan. Hal ini dapat dilihat dimana jumlah peserta didik yang mencapai ketuntasan hanya 17 orang dengan rerata nilai 63,15 dan persentase ketuntasan belajar klasikal peserta didik $65,38 \%$ dinyatakan belum tuntas. Berdasarkan ketetapan SMPN 8 Kota Bengkulu yang menyatakan bahwa hasil belajar peserta didik dapat dinyatakan tuntas secara klasikal apabila mencapai $\geq 75 \%$. Sedangkan hasil belajar peserta didik pada siklus II jumlah peserta didik yang mencapai ketuntasan belajar klasikal sebanyak 20 orang dengan rata-rata nilai 75,69 dan persentase ketuntasan belajar klasikal peserta didik 76,92\% dinyatakan tuntas. $\mathrm{Hal}$ ini sesuai dengan penelitian Alfonsa (2016) yang menyatakan bahwa penerapan model pembelajaran kooperatif tipe jigsaw membantu meningkatkan motivasi dan hasil belajar peserta didik sehingga dapat menjadi salah satu metode dalam proses pembelajaran di dalam kelas.

Dari hasil proses pembelajaran yang telah dilakukan diketahui bahwa proses pembelajaran yang dilakukan berhubungan dengan hasil belajar yang akan didapatkan, karena semakin baik proses pembelajaran yang dilakukan maka hasil belajar juga akan semakin baik. Hal ini sejalan dengan pendapat Slameto (2010), bahwa sebagian hasil belajar merupakan dampak tindakan guru, suatu pencapaian tujuan pembelajaran. Dari hasil penelitian yang dilakukan dengan menggunakan model kooperatif tipe jigsaw dapat meningkatkan aktivitas mengajar guru dan aktivitas belajar peserta didik serta hasil belajar peserta didik.

\section{PENUTUP}

\section{Simpulan}

Pembelajaran dengan model koopetaif tipe jigsaw pada materi Pencemaran Lingkungan dapat meningkatkan aktifitas mengajar guru dan aktivitas belajar peserta didik kelas VII.1 SMPN 8 Kota Bengkulu. Aktifitas mengajar guru disiklus I dengan skor 27 (Baik) meningkat menjadi menjadi 29 (Baik) disiklus II. Aktifitas belajar peserta didik disiklus I dengan skor 27 (Baik) meningkat menjadi 29 (Baik). Perbaikan pembelajaran dengan menerapkan model kooperatif tipe jigsaw dapat meningkatkan hasil belajar peserta didik di kelas VII.1 SMPN 8 Kota Bengkulu pada materi Pencemaran Lingkungan dengan kriteria tuntas yakni $76,92 \%$.

\section{Saran}

1. Guru dapat menerapkan model pembelajaran kooperatif tipe jigsaw sebagai alternatif model pembelajaraan IPA-biologi pada materi pencemaran lingkungan untuk meningkatkan aktivitas dan hasil belajar peserta didik.

2. Dalam menerapkan model kooperatif tipe jigsaw diharapkan guru dapat menguasai tahapan pembelajaran dengan baik agar prose pembelajaran.

3. Penerapan model pembelajaran kooperatif tipe jigsaw membutuhkan instruksi yang jelas kepada peserta didik. Oleh karena itu, intruksi harus dipersiapkan sebaik dan sejelas mungkin sehingga peserta didik tidak mengalami kebingungan.

\section{DAFTAR PUSTAKA}

Abdulhak, I. 2001. Komunikasi Pembelajaran Pendekatan Konvergensi Dalam Peningkatan Kualitas Dan Efektivitas Pembelajaran. Bandung : UPI.

Alfonsa, Diana. 2016. Penerapan Model Pembelajaran Kooperatif Tipe Jigsaw untuk meningkatkan motivasi dan hasil belajar pada materi pencemaran dan kerusakan 
lingkungan kelas VIIB SMP Kanisius kalasan Yogyakarta. Skripsi. Yogyakarta : Universitas Sanata Dharma.

Ardianto. A. 2013. Efektifitas Penerapan Model Kooperatif Tipe Jigsaw Terhadap Prestasi Belajar Mata Pelajaran Akutansi Peserta didik Di SMA Negeri 2 Karanganyar Tahun Ajaran 2011/2012, Jurnal Pendidikan, UNS. Diakes dari http://jurnal.fkip.uns.ac.id/index.php/ekon omi/article/view/2181/1582(pada tanggal 1 April 2018)

Hanafiah, Nanang. 2010. Konsep Strategi Pembelajaran. Bandung: PT. Refika Aditama

Isjoni. 2010. Cooperative Learning: Efektivitas Pembelajaran Kelompok. Bandung : Alfabeta.

Majid, Abdul. 2014. Strategi Pembelajaran. Bandung : PT. Remaja Rosdakarya.

Nur. 2011. Model Pembelajaran Kooperatif. Jakarta: academia

Rahmaeta, Ika. 2012. Penerapan Model Pembelajaran Kooperatif Tipe Jigsaw Untuk Meningkatkan Aktivitas Dan Hasil Belajar Peserta didik Kelas V Pada Materi Perjuangan Mempertahan Kemerdekaan Di SD Negeri 04 Bulu Pemalang. Jurnal. Universitas Negeri Semarang.

Siska, F. 2013. Penerapan Model Pembelajaran Kooperatif Tipe Jigsaw Sebagai Upaya Meningkatkan Minat Dan Hasil Belajar Biologi Materi System Peredaran Darah Manusia Pada Peserta didik Kelas VIII SMP Joanes Bosco Yogyakarta. Skripsi, Universitas Santa Dharma. Yogyakarta.

Slameto. 2010. Belajar Dan Faktor-Faktor Yang Mempengaruhi. Jakarta :Rineka Cipta
Slavin, R.E. 2014. Cooperative Learning: Theory, Reaserch and Practice (penerjemah Nurulita). Bandung: Nusa Media

Sudjana,N. 1989. Dasar-Dasar Proses Belajar Mengajar. Bandung: Sinar Baru.

Sudjana,N. 2009. Penelitian Hasil ProsesBelajar Mengajar. Bandung : Remaja Rosdakarya.

Suparman, dkk. 2014. Penerapan Model Pembelajaran Kooperatif Tipe Jigsaw Untuk Meningkatkan Aktivitas Dan Hasil Belajar IPA Pada Konsep Pencemaran Lingkungan. FKIP Uiversitas Khairun, 11(1):294 (online) (http://ejournal.unkhair.ac.id/index.php/ bioedu/issue/view/14)Jurnal- Universitas Khairun diakses pada tanggal 26 November 2017.

Yuliana, Melisa. 2012. Penelitian Pengaruh Model Kooperatif Tipe Jigsaw Terhadap Hasil Belajar Biologi Peserta didik Kelas VII.1 SMPN 1 Pondok Kelapa.Skripsi.Bengkulu. UNIB. Tidak Dipublikasikan. 